\title{
Teaching as Performance Studies: Exploring the Pedagogical Content Knowledge (PCK) of Theater Arts
}

\section{Mohd Azly Zakaria, Muhammad Faisal Ahmad}

To Link this Article: http://dx.doi.org/10.6007/IJARBSS/v11-i2/9197

Received: 11 December 2020, Revised: 15 January 2021, Accepted: 02 February 2021

Published Online: 25 February 2021

In-Text Citation: (Zakaria \& Ahmad, 2021)

To Cite this Article: Zakaria, M. A., \& Ahmad, M. F. (2021). Teaching as Performance Studies: Exploring the Pedagogical Content Knowledge (PCK) of Theater Arts. International Journal of Academic Research in Business and Social Sciences, 11(2), 1213-1226.

Copyright: (c) 2021 The Author(s)

Published by Human Resource Management Academic Research Society (www.hrmars.com)

This article is published under the Creative Commons Attribution (CC BY 4.0) license. Anyone may reproduce, distribute, translate and create derivative works of this article (for both commercial and non-commercial purposes), subject to full attribution to the original publication and authors. The full terms of this license may be seen at: http://creativecommons.org/licences/by/4.0/legalcode

Vol. 11, No. 2, 2021, Pg. 1213 - 1226

Full Terms \& Conditions of access and use can be found at http://hrmars.com/index.php/pages/detail/publication-ethics 


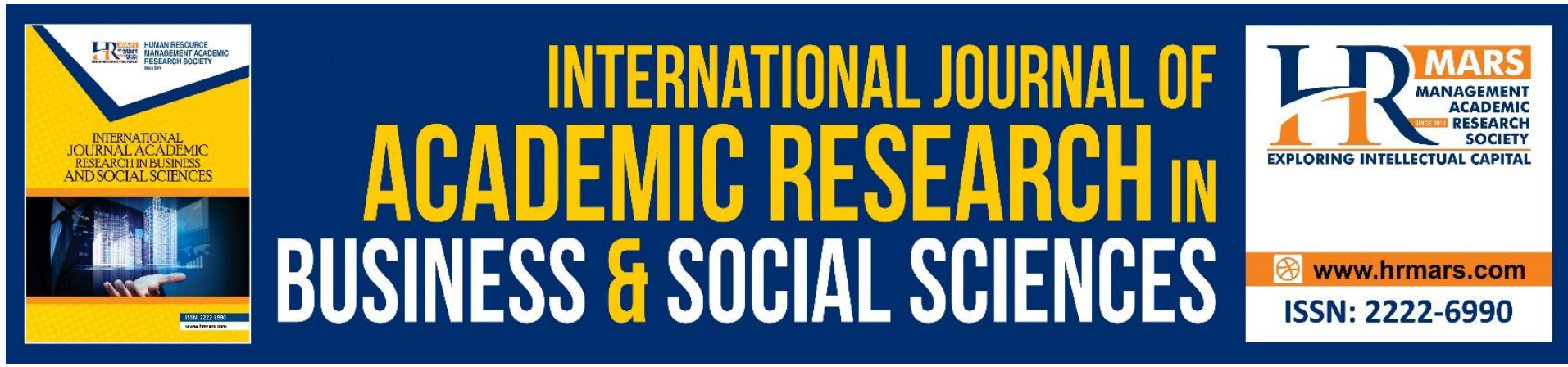

\title{
Teaching as Performance Studies: Exploring the Pedagogical Content Knowledge (PCK) of Theater Arts
}

\author{
Mohd Azly Zakaria, Muhammad Faisal Ahmad \\ Faculty of Music and Performing Arts, Sultan Idris Education University, Malaysia
}

\begin{abstract}
This study was conducted to explore the knowledge of the acting method, pedagogical skills of acting in teaching. Therefore, by researching to understanding Pedagogy Content Knowledge (PCK) by Shulman (1986) through the Secondary School Standard Curriculum, Malaysian Arts School in the implementation of the theater arts curriculum, and how study participants make transformations into lesson plans as well as implementing teaching with the curriculum. Through the literature review discussing the general knowledge of content knowledge, teachers' pedagogical skills knowledge on the use of acting techniques in depth. This study is a qualitative case study with three art school Malaysian Arts School coaches selected as study participants who do not have a background of specialization and professional qualification of theater-specific performing arts and drama as well as basic knowledge and existing skills only through experience by themselves. Data collection was done through interview protocols, teaching observation protocols, and document content analysis. Interviews were conducted to find out the background of the study participants and their understanding of pedagogical content knowledge of curriculum, teaching observations for each study participant was conducted to explore the prior knowledge of teaching and teaching implementation skills, as well as document content analysis, was done based on the purpose of the study submitted. Contribution of this study to improve and develop teaching professionalism in education, provision of resources in curriculum development, and preparation of guidelines and references of theater programs in education at the Ministry of Education Malaysia and Ministry of Higher education.
\end{abstract}

Keywords: Content Knowledge, Pedagogical Knowledge, Curriculum Development, Theater Arts, Acting Method

\section{Introduction}

The Ministry of Education Malaysia (MOE) has introduced the Malaysian Education Development Blueprint 2013-2025 which focuses on ideas related to the role of teachers as facilitators. A plan has issued guidelines and goals that need to be achieved in Malaysian education. MOE has launched curriculum reform through the implementation of the Secondary School Standard Curriculum (KSSM) since 2011. The development of this curriculum was later improved with the implementation of KSSM (Revised) starting in 2017. 
This new curriculum focuses on aspects of skills and competencies that can meet the needs 21st century education. MOE encourages teachers to take initiatives in self-development to improve knowledge and skills as well as apply new teaching practices that are able to meet the needs of the 21st century as stated in PPPM 2013-2025. Effective teachers during the teaching and Learning process is the main measure of student success (Paolini, 2015).

Epistemology is the theory of knowledge and is one of the contents of the study of the nature of knowledge critically, structured and systematic about the process of how knowledge is acquired by humans (Simon, 2013). In 1986, Lee Shulman introduced an effective teaching model known as the Pedagogical Content Knowledge Model (PCK) or Content Pedagogical Knowledge (PPIK). Through the model Shulman (1986) has stated, in order to provide effective teaching, a teacher needs to be an expert on the subjects taught. In other words, a teacher needs to know about 'what' to teach and 'how' to teach something to students. Therefore, Shulman (1986) stressed that teachers need to master two components of knowledge, namely the knowledge of content and pedagogy or skills of a subject. Epistemology is the theory of knowledge and is one of the contents of the study of the nature of knowledge critically, structured and systematic about the process of how knowledge is acquired by humans (Simon, 2013). In 1986, Lee Shulman introduced an effective teaching model known as the Pedagogical Content Knowledge Model (PCK). Through the model Shulman (1986) has stated, to provide effective teaching, a teacher needs to be an expert on the subjects taught.

\section{Background}

Malaysian Arts School was established to provide opportunities and space for young Malaysians to work in the arts and not only rely on certain careers but also they can form careers in the arts (Sports, Co-Curriculum and Arts Division, 2013). In preparation for the implementation of art schools in 2007, the Center for Curriculum Development has taken the initiative to provide orientation courses to teachers appointed by the Ministry of Education Malaysia (MOE). The teachers have been exposed to a curriculum that is specially prepared for art schools and these subjects include the disciplines of Visual Arts, Dance Arts, Theater Arts, and Music Arts.

Malaysian Arts School teachers are appointed as trainers who are directly responsible for implementing the art school curriculum and play a key role in shaping the learning outcomes for each of the pillars of learning taught. Teachers need to be creative and innovative to produce effective teaching and learning because they play as a role model to be more competitive in any aspect of education especially maximizing understanding content of knowledge (Muhamad Zaki Samsudin, Razali Hassan, Azman Hasan \& Mohd As'ed, 2013).

Accordingly, teachers need to prepare themselves with knowledge, skills, and positive attitudes following the requirements of the curriculum, because in implementing the teaching process, teachers are knowledgeable and most qualified individuals to choose effective and most appropriate strategies (McKenney \& Voogt, 2017).

Furthermore, Malaysian Arts School teachers are responsible for playing an active role in the teaching and learning process until desired student behavior changes occur, in-depth knowledge of content knowledge (Shulman, 1986), knowledge of pedagogical skills and practices appropriate to age and student experience taught (Ausubel, 1975 in Subahan, 1999) and the strategies used can help students gain meaningful learning (Kriek, 2016).

The art of theater is a new revision subject in the education system in Malaysia (Curriculum Development Division, 2017). Teachers who teach new subjects have problems 
in mastering the content as well as teaching approaches that are appropriate to the subject. Meanwhile, a study conducted by Fadillah (2014) on the pedagogical practice of teachers found that the pedagogical practices of the trained teachers involved are still conventional, not diverse, using acting techniques and teacher-centered.

The desire to produce theater in education is harmonized and applied in other subjects so that this specific program or curriculum can form future teachers who teach existing and new subjects can master any knowledge of content pedagogy according to Shulman (1986) because with PCK approach the theater arts curriculum is also a teaching approach that is suitable for all types of problem-based subjects and projects based learning as constructive learning.

Besides, the Malaysian Arts School Coaches who teach theater arts subjects are teachers who do not have any specialization to teach those subjects. Abroad, studies on nonspecialization teachers reveal that these teachers do not understand the needs of each subject curriculum they teach so that their teaching and learning does not help students to achieve what is required in the planned curriculum (Elizabeth \& Plessis, 2019).

Lack of understanding of the subject curriculum causes non-specialization teachers to tend to change some parts of the curriculum to elevate the national education system to a higher and world-class level. It will also provide students to ensure that the MOE's aspirations are achieved according to their respective understandings and only teach the parts they understand (Faulkner, 2016).

Non-specialization teachers also often have a misunderstanding of the content of the subjects taught (Kim, 2011). Lack of understanding of the content knowledge and pedagogical causes the teachers involved failing to convey the actual content of the subject well (Nixon, Luft, \& Ross, 2017). Meanwhile, a study by Umi Kalsum Mohd Salleh \& Fonny Hutagalung (2016) found that non-specialization teachers face the problem of applying a teaching and learning approach that is appropriate to the topic due to failure to master the information in the topic taught.

In terms of confidence in implementing teaching and learning, non-specialization teachers are found to be less confident when conveying information and there is often less effective communication among teachers and students (Paolucci \& Dwyer, 2017; Plessis, 2018). The ability of non-specialization teachers in controlling the class during teaching and learning sessions is relatively weak compared to those with specialized expertise in the subjects taught (Kam et al., 2018).

Teachers play a big role in efforts to attract students' interest and enjoyment to stay in the learning environment (Pella, 2015). Accordingly, every teacher needs to have a professional academic qualification and formal education in a subject to have in-depth knowledge of the subject and be able to diversify teaching approaches to deliver effective teaching and learning while in the classroom (Chien Lee Shing et al., 2015). However, the main issue that arises among theater arts subject coaches is that most of them do not have the professional qualifications to teach the subject. In other words, these teachers are nonspecialization teachers in theater arts subjects. Also, the subject of theater arts is new in the Malaysian education system.

\section{Problem Statement}

Problems exist when the education system in Malaysia through the first phase shift of the Malaysian Education Development Blueprint starting 2013-2025 in improving the quality of the teaching profession. Towards teaching and learning in 21st Century in the production of 
in-depth teaching and learning such as using inquiry approaches through activities such as project-based learning, problem-based learning, and cross-curricular teaching approaches (Amran \& Rosli, 2017). In addition to supporting the training of the country's creative work industry towards problem-solving and decision making a performance production presentation.

Malaysia Arts School coaches still lack knowledge of curriculum content and pedagogical. Knowledge needs to be imparted in an integrated manner into the learning activities of Azmi \& Nurzatulshima (2017). Teachers need to be proficient in various teaching techniques in order to provide opportunities for students with various learning needs to unearth their greatest potential. Here, creativity is an important element that empowers teachers' ability to generate and apply as many ideas and techniques as possible and communicate new ideas effectively

Theater Arts Curriculum is a new subject in the education system in Malaysia. According to Suyanto (2017), teachers who teach new subjects have problems in mastering the content as well as teaching approaches appropriate to the subject. This study was conducted by (Baharudin Saleh et al., 2018) on pedagogical practices.

Besides, Malaysian Arts School coaches are still weak on the importance of knowledge of pedagogical skills in the context of the artistic elements in tackling the challenges of the world of globalization and the challenges ahead in the 21st-century learning era. It is the responsibility of teachers to take the initiative in maintaining the interest and motivation of students by applying various meaningful techniques and approaches in the teaching and learning of (Iberahim, Mahamod \& Mohamad, 2017).

From the aspect of confidence in implementing teaching and learning, nonspecialization teachers were found to be less confident when conveying information and there is often less effective communication among teachers and students (Paolucci \& Dwyer, 2017; Plessis, 2018). Teachers' abilities are not specialization in controlling classes during teaching and learning sessions is relatively weak compared to teachers who have specialized expertise in the subjects taught (Kam et al., 2018).

Therefore, this study is necessary to examine how art school coaches in practicing teaching through the aspects of Pedagogical Content Knowledge (PCK) by Shulman (1986). Also, this study is needed to identify and explore the transforming teaching through knowledge and skills in acting refers to learning objectives in the Content and Assessment Standards Document, Secondary School Standard Curriculum, Theater Arts. Besides, this study formed a coach to apply acting techniques in the subject of theater arts. Besides, the contribution of theater in education as well as the field of theater studies in Malaysia. This study uses the PPIK theoretical framework by Shulman (1986) as the basis of the study theory.

\section{Research Questions}

1. How is the content knowledge of theater arts coaches in the implementation of teaching?

2. How are the pedagogical skills knowledge of acting theater arts coaches in the implementation of teaching?

\section{Theoretical Framework of Model Pedagogical Content Knowledge (PCK) in Theather Arts Curriculum}

PCK is the core knowledge of teaching that covers curriculum, assessment, and pedagogy by Shulman (1986) where it includes teaching, learning, curriculum, assessment, and reporting 
that underlies the way of teaching delivery to students. Shulman (1987) also stated that teachers who teach without knowing aspects such as curriculum and assessment are not able to meet the learning needs of students. In 1986, Shulman introduced Content Pedagogy Knowledge (PCK) as a complex knowledge encompassing knowledge and skills namely the approach of conveying content pedagogy knowledge effectively (Shulman, 1986) as shown in Figure 1 below:

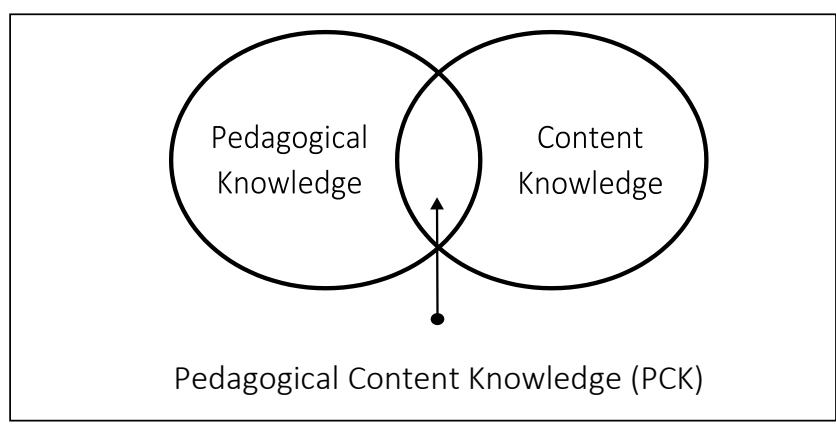

Figure 1. Combination of Content Knowledge and Pedagogical Knowledge Produces Pedagogical Content Knowledge (PCK), (Adapted from Shulman, 1986)

Pedagogy Content Knowledge (PCK) is an important element in the teaching process for each teacher despite different subjects (Nelson Jinggan, 2015). Content knowledge is the teacher's knowledge of the content presented to students. Accordingly, teachers need to master the content such as concepts, theories, ideas, frameworks, descriptions, and evidence as well as the practices needed towards developing that knowledge. Theater arts teachers need to know the content contained in the Theater Arts Curriculum to transform acting techniques in teaching.

Pedagogical knowledge is a unique type of knowledge for a teacher based on the way teachers relate pedagogy to the content of a discipline or what needs to be taught (Chee et al., 2018). Pedagogical knowledge is the knowledge of the types of pedagogy that can be used to support effective teaching that includes knowledge of the processes and practices used in teaching. Teachers who teach new subjects have problems in mastering the content as well as teaching approaches appropriate to the subject (Suyanto, 2017).

Teachers' pedagogical knowledge plays an important role as it integrates content and pedagogy for the formation of an understanding of how teaching topics, problems, and issues are organized, represented, and adapted based on the various interests and abilities of students (Baharudin Saleh et al. 2018). Also, teachers need to research pedagogical theories specifically so that they do not lag in strengthening teaching methods to produce a quality teaching and learning environment. Acting skills produced by teachers can train meaningful and effective teaching and those skills can provide training in teaching.

\section{Literature Review}

\section{Teaching as a Performance Studies}

The argument of teaching as a performing art has been around for several decades until now and many scholars as to teacher (Griggs, 2001; Hanning, 1984; Hart, 2007; Özmen, 2011; Sarason, 1999). Comparing the acting and teaching professions, studies have argued that both teachers and actors must achieve active communication verbal and nonverbal in their teaching as acting process (Griggs, 2001), employ aesthetic aspects to capture and sustain attention (Tauber \& Mester, 2007), and operate their 'selves' as teachers to communicate with their students as an audience (Hanning, 1984). 
The theoretical of pedagogical content knowledge assumptions of creative pedagogy requires artistic skills (Dunn \& Stinson, 2011) and enthusiastic teaching to ensure learners' involvement and to bring the acting craft into play (Tauber \& Mester, (2007). Among these scholars, there is a general accord with the idea that considering teachers as performing artists has an influential impact on the practice and production of teacher education (DeLozier, 1979; Eisner, 1979; Griggs, 2001; Hart, 2007; Sarason, 1999; Travers, 1979; Tauber, Mester \& Buckwald, 1993; Tauber \& Mester, 2007).

The proponents of teaching as a performing art argue that teachers need to build a 'character' (Colley, 2012), an 'identity' (Özmen, 2011), a 'teacher-self' (Hanning, 1984) or 'teacher-in-role' (Kempe, 2012). Hanning (1984) advises 'being yourself' in class but later modifies it to 'making yourself' in your creative way, upon discovering that novice teachers create a teacher-self while performing in class. However, most teacher education programs seem to neglect these goals (Hart, 2007; Sarason, 1999) and graduate unprepared teachers with little or no rehearsals of teaching and acting skills (Cahnmann-Taylor \& Souto-Manning, 2010). Because a sense of professional identity will contribute to teachers' self-efficacy, motivation, commitment, and job satisfaction" (Flores \& Day, 2006, p. 220), these programs need to effectuate the conception that teachers need teaching and acting skills to develop personal and professional characters. There has not been much research on the effects of creative drama on pedagogical skills and identity formation of student teachers.

Model of Performing Arts Techniques across the curriculum, through the writing of Mohamad Nazri Ahmad (2008) entitled "Seni Lakon Mencerminkan Sikap Masyarakat" has provided some acting techniques that inspire educators. This study is supported by Muhammad Faisal Ahmad (2012) and Fadillah Mansor (2014) state that acting art techniques in teacher teaching are in line with performing arts. Becoming a teacher means adopting both a personal and a professional identity since teaching is already a complicated task that involves analyzing situations, rethinking learner-based variables, and creating a teacher-self in the given circumstances. However, identities are multiple, shifting, and in-conflict (Varghese, Morgan, Johnston, \& Johnson, 2005) and go through changes in varying contexts (Day, Kington, Stobart, \& Sammons, 2006).

Robert Cohen (1978) in his book Acting Power, acting has applied a form of artistic work in which the actors imitate the character or character in a form of performance directly based on a script as well as teachers imitate as the basis of acting in teaching. As teachers bring both personal and professional identities to the classroom (Buchanan, 2015), they are inevitably affected by personal and professional factors including self-issues, curricular issues, student-related issues, and external issues like time and support (Oreck, 2004).

In terms of effective teaching skills, this effect is usually defined as abilities and awareness in verbal and nonverbal communication (Vandivere, 2008). Teachers need to have imitation techniques to facilitate effective communication with students. Theater in the development of our education is talking about art or acting activities applied to education. Similarly, language teacher identity is influenced by both personal histories such as prior life experiences, and professional factors including curriculum, administration, and social demographics (Miller, 2009).

Solehah Ishak (2001: 17-21) states that drama is an academic study material that is unique enough to study character and characterization. Teachers can apply in skills drama can be studied through the text and its authorship process, its production and authorship process, its presentation and audience, the field of education, aesthetics, and various aspects of its artistic refinement. Teachers need to have imitation techniques to facilitate effective 
communication with students in producing effective acting. Teacher identity can be developed through acting skills (Griggs, 2001; Hanning, 1984; Hart, 2007; Özmen, 2011) because teaching as a performing art has transformative effects on teacher identity (Hart, 2007).

Somers (2015), the drama was only initially recognized as a subject or topic that was taught or used as a teaching technique in England between World War One and World War Two. Initially, it was introduced in schools and was mainly experimental in its structure. Rahmah Bujang (Rahmah Bujang 1994: 30) stated theater and drama is a creative drama activity that includes two fields of art, namely literary art through scripts and performing arts through staging media, drama education in schools, among others, aims to encourage students to get involved in understanding something subject and enable teachers in the practice of discipline and moral values through ethics in acting. Creative drama, a powerful tool in language teaching, relies on creating a fictional world to explore ideas, subjects, problems, and relationships with a group using role-plays, improvisations, and other techniques (O'Neill, 1995).

Through his work of 'Poetrics' and 'Rhetoric', Aristotle sees art, especially stage media performances such as drama as an imitation of life that may not depict life but from it because of screening and taking essence from the elements of life, until the imitation produces certain satisfaction to participants (Rahmah Bujang 2002: 145). Teachers need to have acting knowledge and skills to facilitate a well-produced production.

Abdul Rahman Napiah (1984: 2) argues acting is a form of fiction that emphasizes dialogue and character action. A complete play was written is called a script. John Adam (1960) as Zainal Latiff (1991: 5) has pioneered education known as Speech Centric in education and introducing role-playing acting in character building and characterization. Teachers can transform skills in teaching.

Mana Sikana (2005), expressed that although acting is a branch of art that is always inclusive but drama techniques can be used in the field of teaching and learning. Robiah Kulup Hamzah (1989: 3) revealed that the application of drama techniques in the classroom can build a high level of intellectual thinking. Through the imagination of the script can train teachers to master acting techniques.

Bella Merlin (2010), acting is a process of action that has evolved dramatically over the past four hundred years but has not been seen specifically by others in the form of evolution. Mohd Nizam (2008) also gave the view that to implement this teaching is necessary to approach acting techniques in teaching and learning so that it is successful and effective.

Zainal Latiff (1991: 4) has introduced his method of play (Play Way) for learning. The basic principle is that acting activities are an effective way of learning, where students learn by making a script-based presentation. This concept has been applied by all educational concepts around the world including Malaysia in teaching and learning now. In addition to including in the School-Based Assessment in items of high validity by the Curriculum Development Division (2017).

Teaching as the performance studies lead a quality education and require motivated teachers and students, an appropriate curriculum, and inclusive, accessible environments, free from any form of discrimination. It involves addressing complex challenges in today's knowledge societies and increasingly knowledge-based cultural sustainability. The concept of "quality education" encompasses respect for and engagement with local communities and cultures (UNESCO, 2005). 


\section{Methodology}

This study is a qualitative design study and based on the constructivism research paradigm. The paradigm of constructivism is a branch of research that aims to explain, understand, and interpret a problem based on the people involved in the study (Merriam, 2009).

In qualitative studies, the study participants involved are usually not numerous and there are no specific rules on how to determine the sample size appropriate to each study conducted (Merriam, 2009; Miles \& Huberman, 1994; Yin, 2009). This is because, in the selection of study participants of qualitative research, the important thing lies not in a large number of participants but the participants who can provide rich raw data and able to answer all research questions until the data reaches saturation (Corbin \& Strauss, 1990; Merriam, 2009).

Therefore, this study only involves three informants from Johor, Kuala Lumpur and Perak Malaysian Arts School selected based on the purposive sampling method or purposeful sampling as suggested by (Creswell, 2012) and meet the characteristics required in this study that study participants must be teachers not specializing in theater arts majoring in background study, has been teaching theater arts subjects at least for three years, has attended Secondary School Standard Curriculum Theater Arts strengthening courses and has been a voluntary study participant.

The main data collection of this study is through a semi-structured interview method and is supported by data from observations and documentary evidence. According to Merriam (2009), the interview method is very suitable to obtain detailed data from study participants and be able to provide data in a short time. There are three purposes of the interview, namely, first to obtain unique information from the individual who is the study participant, second to obtain an honest confession or statement from the study participant and third is to obtain detailed information on something that can not be obtained during observation (Stake, 2010).

Meanwhile, the observation method was performed as supporting and validating the data from the interview method. Through observation, researchers can collect 'nonverbal' data to examine real situations or events in addition to being able to critically observe the behavior of study participants (Creswell, 2012).

The following method of data collection is document analysis. Based on Creswell (2012) and Merriam (2009), documents can provide very useful data to help researchers understand a phenomenon in more depth and can be real evidence that can be seen, felt, and held. The documents in this study are as follows, Annual Teaching Plan, Teacher's Daily Lesson Plan, Curriculum and Assessment Standard Document, and other related documents.

Study data were obtained from the results of interviews, observations, and document analysis by the three theater arts trainers who were the sample of this study. The data collected in this study is managed and analyzed using the method of data analysis used in obtaining results is thematic and detailed descriptions produced at each level of coding to achieve a level of saturation of categories and themes that help to produce accurate findings to support research theory.

\section{Contribution}

Theoretically, scientific studies on these theories and models can be applied by the Ministry of Education (MOE) and Ministry of Higher Education (MOHE) in particular to assist teachers and prospective teachers of specialization and no specialization in the field of theater in 
contributing to the development of PPIK teachers. Improvement of conceptual framework and curriculum.

Methodologically, this study is also important to realize the eighth shift of "transformation of educational abilities and delivery capabilities" contained in the Malaysian Education Development Blueprint 2013-2025.

Practically, the knowledge and techniques and approaches of this model can stimulate the development of knowledge and skills of a teacher and 'role model' because this study can help the conceptual framework for the implementation of teacher teaching.

Achieving the objectives of the Malaysian Arts School is important to produce students who are balanced in academic achievement and arts (Sports, Co-Curriculum and Arts Division, 2020).

For the MOE and MOHE, the application of this study is used by the State Education Department and the District Education Department as well as schools under it, which can conduct industrial training, workshops, or programs to improve the skills of teachers including coaches appointed.

\section{Conclusion}

The teaching of theater arts can enhance the development of the profession in education in mastering pedagogical content knowledge and skills theoretically and practically. Based on these goals, this research is implemented based on improving the quality of the teaching profession proposed by the Malaysian Education Development Blueprint, Ministry of Education Malaysia 2013-2025. The success of the Ministry of Education Malaysia depends on the commitment and understanding of all KPM staff on its implementation policies and strategies. Malaysian Education Development Blueprint is important because it will provide a strong foundation to push the country's education system to a higher and world-class level. It will also provide perfect human capital as a whole to ensure quality and realize the aspirations of the Ministry of Education Malaysia is achieved.

Pedagogical Content Knowledge in teaching and learning in the classroom is a skill that should be mastered by teachers. Because with this knowledge, a teacher can adapt the content of a subject by the needs of students' understanding. Meaningful teaching and learning are greatly influenced by the teacher's ability to deliver good and effective teaching in the classroom (Pella, 2015; Shulman, 1987).

Effective teaching is important so that students can optimize the learning outcomes received and in turn help, students build themselves to become a 21st century generation. Therefore, a teacher needs to prepare themselves with content knowledge as well as pedagogical knowledge of the subjects taught to students. Past studies prove that these two components of knowledge are interrelated and have an important role in helping teachers design effective teaching and learning implementation (Ball et al., 2008; Shulman, 1986).

The implementation of the Theater Arts Curriculum in Malaysia which has just entered its $3 r d$ year at the secondary school level creates new challenges for the teachers as coaches who teach the subject, moreover almost most of the coaches teach the subject are nonspecialization teachers in the field of theater. The research problem proves the high need in researching content knowledge and pedagogical knowledge of theater arts subjects. That creates a space for future improvement. In this regard, the authorities need to be more proactive to provide exposure related to the subject to the coaches involved. Continuing strengthening courses and training related to the subject should be well planned and provide an opportunity for all teachers to participate in the course or training. Besides, teachers 
should also be open and positive to accept the changes that occur in the education curriculum and always look for opportunities to improve and strengthen content knowledge and pedagogical knowledge for the subjects taught.

Further research related to the field of theater arts subjects needs to be done to find other problems faced by the coaches who teach those subjects and suggestions for improvement. Theoretically, scientific research on this study can be applied by the Ministry of Education Malaysia and the Department of Higher Education in particular to help teachers and prospective teachers' specialization and no theater and drama specialization in contributing to the development of teacher pedagogical content knowledge. A quantitative study involving a large sample is proposed as a further study to deepen the mastery of pedagogical content knowledge of theater arts subject teachers. Also, research involving students as a sample of research should be carried out to explore issues or problems related to theater arts subjects from the perspective of students. Improving the concept and curriculum framework can also help further studies as well as to improve and develop coaching professionalism in education, provision of resources in curriculum development, and preparation of guidelines and reference of theater programs in education at the Ministry of Education Malaysia (MOE).

\section{Acknowledgment}

1. Dr. Muhammad Faisal bin Ahmad

2. Prof. Madya Dr. Mohd Kipli bin Abdul Rahman

\section{Corresponding Author}

Dr. Muhammad Faisal bin Ahmad

Faculty of Music and Performing Arts Sultan Idris Education University Perak, Malaysia Email: mfaisal@fmsp.edu.my

\section{References}

Ahmad, M. F. (2012). Teknik Seni Lakon Dalam Pengajaran: Satu Kajian Kes Di Negeri Selangor. Universiti Kebangsaan Malaysia.

Ahmad, M. N. (2008). Seni Lakon Mencerminkan Sikap Masyarakat. Bangi: Penerbit Universiti Kebangsaan Malaysia.

Amir, M. (2019). Kaedah Teater Membaca Dalam Pengajaran Dan Pembelajaran Genre (Drama). Jabatan Bahasa Dan Kesusasteraan Melayu, Universiti Pendidikan Sultan Idris.

Azmi, M. N., \& Kamarudin, N. (2017). Penerapan Kemahiran Berfikir Aras Tinggi (KBAT): Kesediaan Guru dalam Pengajaran dan Pembelajaran Reka Bentuk dan Teknologi (RBT) di Sekolah Rendah. International Research Journal of Education and Sciences, 1(1), 1-5.

Bujang, R. (1997). Drama Sebagai Satu Bidang Pengajian di Sekolah. Jurnal Pengajian Melayu, 7, 92-103.

Bujang, R. (Penys.) (1982). Drama Melayu 25 Tahun. Kuala Lumpur: Dewan Bahasa dan Pustaka.

Cathrine, M. (2019). Pengetahuan Pedagogi Kandungan (PPK) Guru Bukan Pengkhususan Reka Bentuk dan Teknologi (RBT) di Sekolah Menengah. Malaysian Journal of Social Sciences and Humanities (MJSSH), 4(6), 64-67 
Corbin, J., \& Strauss, A. (1990). Grounded Theory Research: Procedures, Canons, and Evaluative Criteria. Qualitative Sociology, 13(1), 3-21.

Creswell, J. (2013). Qualitative Inquiry and Research Design. London: SAGE.

Creswell, J. (2014). Research Design. London: SAGE.

Creswell, J. W. (2012). Educational Research (Planning, Conduction, and Evaluating Quantitative and Qualitative Research) (4th Ed). Boston: Pearson.

Elizabeth, A., \& Plessis, D. (2019). Barriers to the effective management of diversity in classroom contexts: The out-of- fi eld teaching phenomenon. International Journal of Educational Research, 93(November 2017), 136-152.

Faulkner, F. (2016). A CPD Programme for out-of-field mathematics teachers: Programme Outline and Preliminary Evaluations by Participants A CPD Programme for 'out-offield' mathematics teachers in Ireland: Programme outline and initial evaluations by ... In Science and Mathematics Education Conference, Dublin City University (pp. 1-7).

Griggs, T. (2001). Teaching as acting: considering acting as epistemology and its use in teaching and teacher preparation. Teacher Education Quarterly, 28, 2, 23-37.

Hanning, R. W. (1984). The classroom as the theater of self: some observations for beginning teachers. Retrieved December 7, 2008, from www.ade.org/ade/bulletin/N077/077033.htm

Hart, R. (2007). Act like a teacher: Teaching as a Performing Art" Electronic Doctoral Dissertations for UMass Amherst.

Iberahim, A. R., Mahamod, Z., \& Mohamad, W. M. R.W. (2017). 21st Century Learning and the Influence of Attitude, Motivation, and Achievements Malay Language Secondary School Student. Jurnal Pendidikan Bahasa Melayu, 7(2) , 77 - 88

Kam, K., Chan, H., Hin, B., \& Yung, W. (2018). Developing Pedagogical Content Knowledge for Teaching a New Topic: More Than Teaching Experience and Subject Matter Knowledge. Res SciEduc, 48, 233-265.

Kementerian Pelajaran Malaysia. (2012a). Pendidikan di Malaysia - Memartabatkan Kecemerlangan Pendidikan Negara. Bahagian Perancangan dan Penyelidikan Dasar Pendidikan.

Kementerian Pelajaran Malaysia. (2012b). Laporan Awal Pelan Pembangunan Pendidikan Malaysia 2013-2025. Bahagian Perancangan dan Penyelidikan Dasar Pendidikan.

Kementerian Pendidikan Malaysia. (2013). Pelan Pembangunan Pendidikan Malaysia 2013 2025. https://www.moe.gov.my/images/dasar-kpm/PPP/Preliminary-BlueprintBM.pdf.

Kementerian Pendidikan Malaysia. (2017). Dokumen Standard Kurikulum dan Pentaksiran. Seni Teater, Tingkatan 1.

Kim, E. (2011). Out-of-field secondary school teachers in Korea: Their realities and implications. KEDI Journal of Educational Policy, 1(8), 29-48.

Kriek, J. (2016). A modified model of TPACK and SAMR in teaching for understanding. In G. Chamblee \& L. Langub (Eds.), Proceedings of Society for Information Technology \& Teacher Education International Conference 2016 (pp. 23-28). Chesapeake, VA: Association for the Advancement of Computing in Education (AACE).

Lakshmi, P. \& Abdul Rahman, M. K. (2020). Aplikasi Teknik Teater Kreatif Dalam Meningkatkan Kesedaran Kognitif Murid-Murid Berkeperluan Khas (Mbk). Journal of Social Science and Humanities, 3 (3), 9-14. 
Mohd, S. U. M., \& Hutagalung, F. (2016). Comparisons of Out of Field and In-Field History Teacher: Teachers' and Students' Characteristics. Advanced Science Letters, 22(8), 1952-1956.

Nixon, R. S., Luft, J. A., \& Ross, R. J. (2017). Prevalence and Predictors of Out-of-Field Teaching in the First Five Years. Journal of Research in Science Teaching, 54(9), 1197-1218.

O'Neill, C. (1995). Drama worlds: A framework for process drama. Portsmouth, England: Heinemann.

Özmen, K. S. (2010). Fostering Nonverbal Immediacy and Teacher Identity through an Acting Course in English Teacher Education. Australian Journal of Teacher Education, 35 (6).

Özmen, K. S. (2011). Acting and teacher education: The BEING model for identity development. Turkish Online Journal of Qualitative Inquiry, 2(2), 36-49.

Palmer, P. J. (2003). The heart of a teacher: Identity and integrity in teaching. In The JosseyBass reader on teaching (pp. 3-25). San Francisco: Jossey- Bass.

Paolini, A. (2015). Enhancing Teaching Effectiveness and Student Learning Outcomes, 15(1), 20-33.

Rives Jr., F. C. (1979). The teacher as a performing artist. Contemporary Education, 51(1), 7-9.

Rodgers, C., \& Scott, K. (2008). The development of the personal self and professional identity in learning to teach. In M. Cochran-Smith, S. Feiman-Nemser, D.J. McIntyre \& K.E. Demers (Eds.), Handbook of research on teacher education: Enduring questions and changing contexts (pp. 732-755). New York: Routledge.

Saleh, B. Rasul, M. S., \& Affandi, H. M. (2018). Pedagogical Practices of Design and Technology Teacher Trainees Pedagogical Practices of Design and Technology Teacher Trainees. International Journal of Academic Research in Business \& Social Sciences, 8(5), 319329.

Sarason, S.B. (1999). Teaching as performing art. New York: Teachers College Press.

Shing, C. L., Mohd, S. R., \& Loke, S. H. (2015). The Knowledge of Teaching - Pedagogical Content Knowledge (PCK). The Malaysian Online Journal of Educational Science,3(3), 40-55.

Shulman, L. S. (1986). Those Who Understand: Knowledge Growth in Teaching. American Educational Research Association, 15(2), 4-14.

Shulman, L. S. (1987). Knowledge and Teaching: Foundations of the New Reform. Harvard Education Review, 57(1), 1-22.

Sikana, M. (2005). Pengajaran dan Pembinaan Bahasa dalam konteks Pendidikan Drama. Jurnal Aktivis, 1(5), 116-138.

Stake, R. E. (2010). Qualitative Research Studying How Things Work (1st Ed, Vol. 136). New York: The Guilford Press.

Suyanto, S. (2017). A Reflection on the Implementation of a New Curriculum in Indonesia: A Crucial Problem on School Readiness. In The 4th International Conference on Research, Implementation, and Education of Mathematics and Science (Vol. 100008, pp. 1-9).

Tauber, R. T., \& Mester, C. S. (2007). Acting lessons for teachers: using performance skills in the classroom (2nd ed.). Westport, Conn: Praeger.

Tauber, R. T., Mester, C. S., \& Buckwald, S. C. (1993). The teacher as an actor: entertaining to educate. NASSP Bulletin, 77 (551), 20-28.

Timpson, W. W., \& Tobin, D. N. (1982). Teaching as performing: a guide to energizing your public presentation. Englewood, NJ: Prentice Hall Inc. 
Travers, R. M. W. (1979). Training the teacher as a performing artist. Contemporary Education. 51(1), 14-18.

Van Hoose, J., \& Hult Jr., R. E. (1979). The performing artist dimension ineffective teaching. Contemporary Education, 51(1), 36-39.

Vandivere, A. H. (2008). An investigation of the nonverbal communication behaviors and role perceptions of pre-service band teachers who participated in theatre seminars. Unpublished Ph.D. Dissertation. University of North Texas, Texas.

Yin, R. K. (2009). Case Study Research Design and Methods (4th Ed). Sage Publications, Inc. 